\title{
Elite Croatian Junior Taekwondo Competitors: Morphological Characteristics and Body Composition Reference Values
}

\author{
Competidores Croatas de Taekwondo Junior de Élite: Características \\ Morfológicas y Valores de Referencia de Composición Corporal
}

Drazen Cular ${ }^{1,2,3}$; Ana Kezic ${ }^{1} \&$ Mario Tomljanovic ${ }^{1}$

CULAR, D.; KEZIC, A. \& TOMLJANOVIC, M. Elite Croatian junior taekwondo competitors: Morphological characteristics and body composition reference values. Int. J. Morphol., 39(3):726-731, 2021.

SUMMARY: The main purpose of this study was to determine the body composition and anthropometric reference values of male and female junior Croatian taekwondo competitors according to official weight category. Additional aim of the study was to identify possible differences in variables between the weight categories. The sample comprised 247 junior participants of the national taekwondo championships divided into male $(\mathrm{N}=121)$ and female $(\mathrm{N}=126)$. The variable sample was defined by a set of 8 measurements: Body height $(\mathrm{cm})$, Body mass (kg), Body mass index, Body fat (\%), Body fat (kg), Muscle mass (kg), Lean body mass (kg) and Total body water (\%). Results confirm previous studies proving that younger taekwondo practitioners have higher levels of body fat than their more experienced peers (seniors). Significant differences were only found between lean and heavy categories. Male junior taekwondo athletes show total body water percentages from 57.4 to $74.8 \%$, with significantly lower percentages in higher weight categories, while female athletes in heigher categories demonstrate a worrying level of hydration status, therefore endangering their performance and overall health. As the first paper that investigates the reference values of junior taekwondo athletes but based on official weight categories it is especially important as each weight category warrant different body composition requirements, as seen from significant differences across different variables. Future studies should include motor abilities inspection throughout the weight categories and possible use of calculation of metabolic age.

KEY WORDS: Normal values; Body build, morphology; Weight reduction; Hydration.

\section{INTRODUCTION}

As a sport that is practiced in more than 200 countries and 5 different continents according to the official World Taekwondo Federation (WTF), taekwondo is definitely to be considered a global sport. It is one of the most popular kicking combat sports, following a polystructural activity with open and semi-open movement structures. Considering that it entered the Olympics only at 2000 in Sydney, it is a relatively young Olympic sport, therefore, only partially investigated concerning the impacts of certain characteristics on success. Previous findings (Toskovic et al., 2004) indicate that a high level of all anthropological dimensions is required for success in taekwondo. However, it is stated that speed and explosive power, which are naturally in the function of specific technical-tactical skills, are the most important. Cular et al. (2013) claim that the specification equation of success in taekwondo, which should reveal the hierarchical structure and mutual relations between the factors important for achieving high taekwondo results, has not been adequately explored yet, at least not to the extent which would allow the use and exact application of the obtained scientific findings in the selection and sports preparation of taekwondo athletes. Sadowski et al. (2012) report that dynamic strength, general endurance, technical skills, complex reactions and low adiposity levels are the factors responsible for better results in elite junior taekwondo athletes. Although a respectful sample, the research was not done based on official weight categories. Instead, the only criterium was chronological age. Scientists agree in their conclusion that one of the key topics in the process of identification, orientation, and development of young athletes is determining the subject's "real" age. Many studies (Malina et al., 2000; Figueiredo et al., 2009; Malina et al., 2010) emphasize the

\footnotetext{
${ }^{1}$ Faculty of Kinesiology, University of Split, Nikole Tesle 6, Split, Croatia.

${ }^{2}$ Croatian institute of kinesiology and sport, Nikole Tesle 6, Split, Croatia.

${ }^{3}$ Einstein, Research, Development, Education, Trade \& Service, Miroslava Krleze 12, Split, Croatia.
} 
importance of biological development and anthropometric characteristics because biologically more mature children are often selected as talents. All kinds of anthropometric characteristics research are important in the function of improvement systems for identification, orientation, and development of sports talents, in this case, taekwondo athletes.

Due to the possibility of taekwondo athletes participating in multiple fights in the same day, aerobic functional capacities, besides anaerobic, should also be developed (Cular et al., 2011), and the percentage of subcutaneous fat tissue should be low (Gao et al., 2001). The most frequently tested segments of anthropological status are athletes' motor-functional abilities and morphological characteristics. This is due to the fact that the measuring instruments used to assess these characteristics have satisfactory metric characteristics, thus the obtained results are exact and interpretable, and are of great importance for success in almost every sport. Another reason is that based on these measurements coaches and experts conduct initial selections of athletes in almost all sports and sport disciplines. Therefore, it is crucial for each of the sports and sport disciplines to have normative values of morphological characteristics and body composition to be able to monitor growth and development of young athletes. This is especially important when hydration is concerned since it has been proved that bodyweight reduction or reduction of body fluids (dehydration) is detrimental, especially if carried out within a short space of time before weighing (Utter et al., 2012), and that intense bodyweight reduction through reducing fluids impacts athletic performance and is associated with tiredness, anger and anxiety (Burke et al., 2009). Bes`lija et al. (2020) found that $54 \%$ of senior taekwondo athletes lose a significant amount of weight just before weighing and, given that health-concerning fact, suggested a new model for taekwondo athletes categorization according to height, which still needs to be tested.

Despite the fact that researchers defined normative values for taekwondo athletes across their countries (Malacko et al., 2015; Jeon et al., 2020), not one study included official weight categories but only chronological age. When taking into consideration the official weighing system, this is not of great importance, because it can be assumed that differences between categories exist. A great review study was done on body composition throughout different countries and on many levels (Bridge et al., 2014), however, it lacks the categorization throughout official weight categories. Another problem is that the studies focusing on elite junior contestants are rare.

The main aim of the study was to determine the body composition and anthropometric reference values of male and female junior Croatian taekwondo competitors according to official weight category. Specific aim of the study was to identify possible differences in variables between weight categories.

\section{MATERIAL AND METHOD}

The subject sample comprised 247 participants of the national taekwondo championships for juniors (Split, Croatia, 2016), divided into two subsamples: male juniors $(\mathrm{N}=121)$ and female juniors $(\mathrm{N}=126)$ and later categorised by weight category. The variable sample was defined by a set of 8 measurements, both morphological measurements and variables defining body composition: Body height $(\mathrm{cm})$, Body mass (kg), Body mass index, Body fat (\%), Body fat $(\mathrm{kg})$, Muscle mass $(\mathrm{kg})$, Lean body mass $(\mathrm{kg})$ and Total body water (\%). The Body height variable was measured by the Martin anthropometer, with scale precision of $0.01 \mathrm{~cm}$, whereas all other variables were analysed by the TANITA diagnostic scale (BC 418), i.e., a monitor which calculates body composition based on electrical resistance which differs depending on the tissue through which the electrical energy is conducted (Bio Impedance Analysis). All measurements were taken in the morning, in the sports hall where the national championship took place, following the predefined protocol that had been announced to the participants and their coaches in advance. Subjects did not consume a meal or ingest larger amounts of fluid before the measurement and 24 before the measurement are refrain from physical activity or training and sauna. Also, subject's bladder was emptied before performing the measurement. Hand-body and thigh contact was avoided during the measurement. A precondition to enter the competition was a clean health status, which was verified by a medical certificate from a certified sports medicine physician. The measurers who performed the measuring were all experts from the Faculty of Kinesiology in Split. The study has been conducted as a part of the project: Biological, chronological and relative age in the function of developing Croatian national sport talent system, supported by the Croatian Science Foundation No. 3366 and the Ethical Board of the Faculty of Kinesiology University of Split, Croatia approved the described protocol (permit number: 2181-205-02-05-20-006). Before taking part in the study, the underaged participants provided a written consent singed by their parent-guardian, i.e., personal statement.

Data analysis methods included the calculation of descriptive statistical parameters: mean value (Mean), standard deviation (SD), minimum result (MIN), and maximum result $(\mathrm{MAX})$ for all 8 variables, separately for male and 
female junior competitors as well as for each weight category. ANOVA (with post-hoc Fisher LSD) was used to determine the differences between categories. For all statistical analysis, type one error was set at $\mathrm{a}=5 \%$. All calculations were performed by using the Statistica v.13 data analysis software system (TIBCO Software Inc., USA).

\section{RESULTS}

Descriptive parameters of anthropometric characteristics and body composition of junior male Croatian taekwondo competitors according to weight category $(-45 \mathrm{~kg},-48 \mathrm{~kg}, 51 \mathrm{~kg}$, $55 \mathrm{~kg}, 59 \mathrm{~kg},-63 \mathrm{~kg},-68 \mathrm{~kg},-73 \mathrm{~kg}, 78 \mathrm{~kg},+78 \mathrm{~kg}$ ) are presented in Table I. A proportional increase in mean values in almost all variables is visible when inspecting data throughout categories with an exception of Total body water (\%) which is decreasing in heavier male athletes. Also, higher categories were significantly heavier, taller, and with higher BMI than the lower ones $(\mathrm{p}<0.01)$, with no differences only between some neighbor categories. When looking at the body fat variable, both in $\mathrm{kg}$ or $\%$, significant differences occurred only between heavier categories $(p<0.01)$, while no differences were found in their leaner counterparts. Muscle and fat-free mass concerning, significant differences were found between almost all categories $(\mathrm{p}<0.03)$ where, naturally, heavier athletes had significantly higher values.

To get a wider picture of Total body water results (\%), data have been shown graphically (Fig. 1) where a big decrease throughout categories is visible. Additionally, analysis of variance showed significant differences between the leanest category ( -45 $\mathrm{kg}$ ) and categories $-59 \mathrm{~kg},-63 \mathrm{~kg},-68 \mathrm{~kg},-73 \mathrm{~kg},-78 \mathrm{~kg}$ and +78 $\mathrm{kg}(\mathrm{p}<0.05)$. Furthermore, leaner categories $(-48 \mathrm{~kg},-51 \mathrm{~kg},-55$ $\mathrm{kg},-59 \mathrm{~kg}$ ) have significantly lower results than categories $-73 \mathrm{~kg}$, $-78 \mathrm{~kg}$ and $+78 \mathrm{~kg}(\mathrm{p}<0.04)$.

Table II presents descriptive parameters of anthropometric characteristics and body composition of junior female Croatian taekwondo competitors according to weight category ( $-42 \mathrm{~kg},-44$ $\mathrm{kg},-46 \mathrm{~kg},-49 \mathrm{~kg},-52 \mathrm{~kg},-55 \mathrm{~kg},-59 \mathrm{~kg},-63 \mathrm{~kg},-68 \mathrm{~kg},+68 \mathrm{~kg}$ ). A similar increase in mean values across categories as in male athletes occurred with some individual exceptions in some variables and with an exception of Total body water $(\%)$ which decreases in heavier female athletes as in males. As in males, higher categories were significantly heavier, taller, and with higher BMI than the lower ones $(\mathrm{p}<0.02)$, with no differences only between a few neighbor categories. Identically to males, significant differences in body fat variable occurred only between heavier categories $(p<0.03)$, while no significant differences were found in leaner athletes. Muscle and fat-free mass proved to be significantly higher in heavier athletes, while differences were found between almost all categories $(\mathrm{p}<0.04)$.

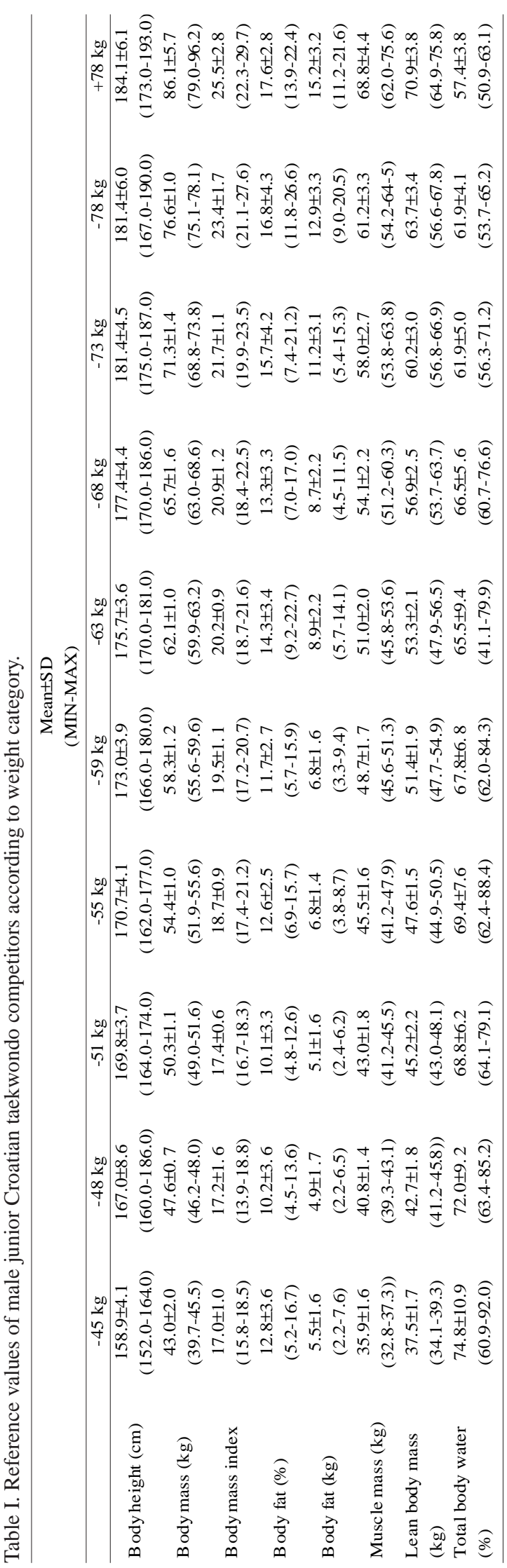




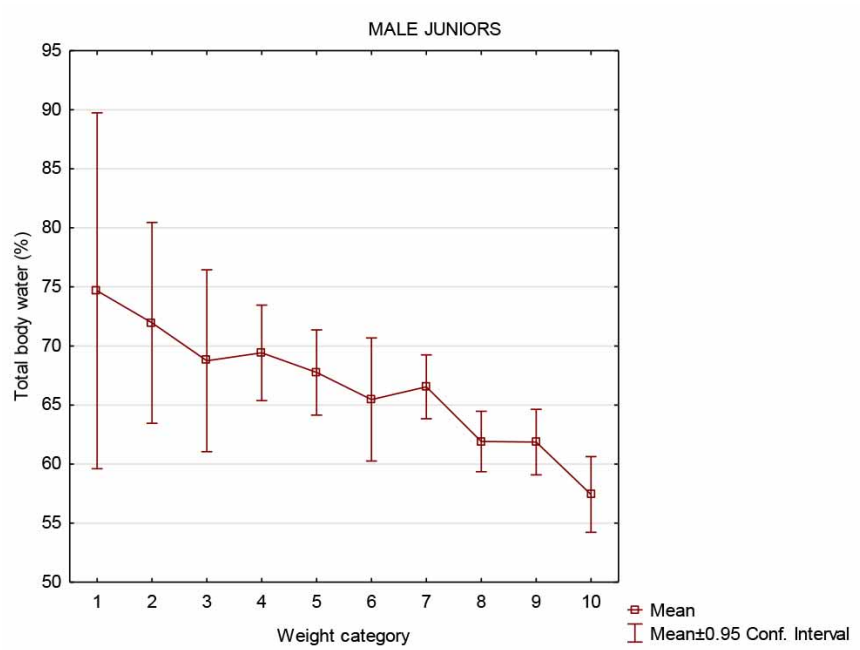

Fig. 1. Results of total body water percentages across junior male categories (from category $1--45 \mathrm{~kg}$ to category $10-+78 \mathrm{~kg}$ ).

Total body water results (\%) for females have also been shown graphically (Fig. 2) where an even bigger difference between different categories than in males is visible. The analysis of variance with post-hoc Fisher LSD test revealed significant differences between almost all categories $(p<0.03)$ with an exception of category $-44 \mathrm{~kg}$ (significant differences only with categories $-44 \mathrm{~kg}$ and $-63 \mathrm{~kg},-68 \mathrm{~kg}$ and $+68 \mathrm{~kg}$ ). So, lighter categories had significantly lower results than the heavier categories $(\mathrm{p}<0.00)$.

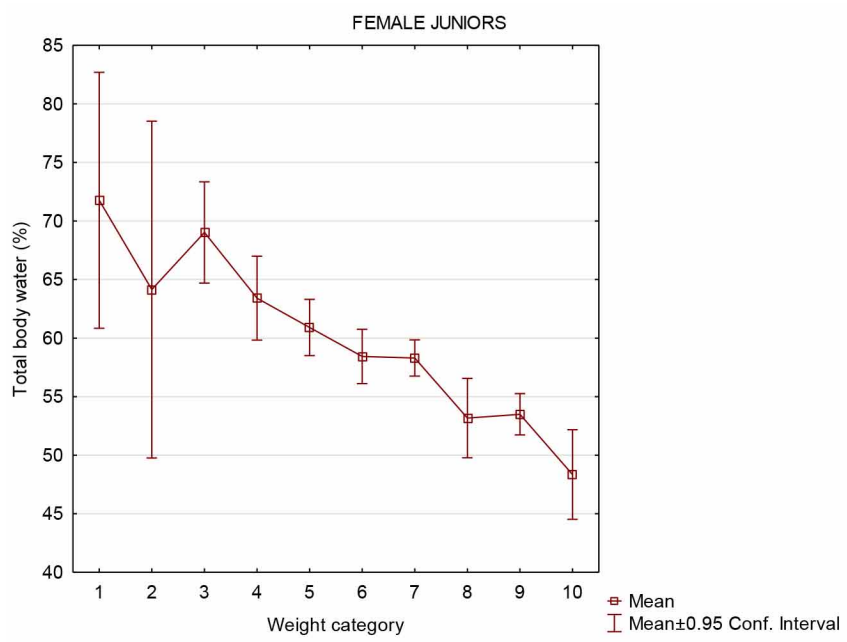

Fig. 2. Results of total body water percentages across junior female categories (from category 1 - -42 kg to category $10-+68 \mathrm{~kg}$ ).

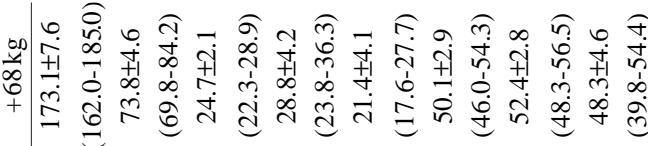

+

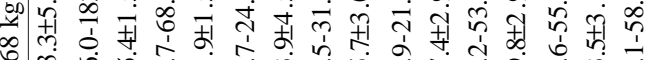

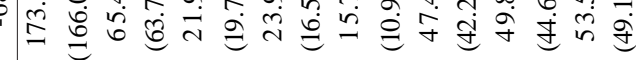

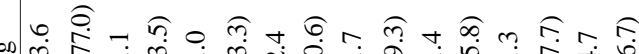

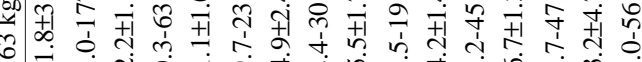

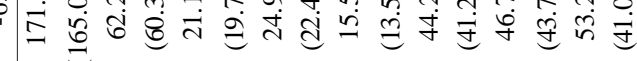

น

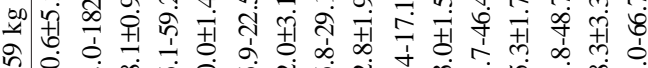

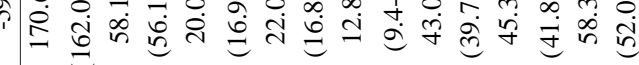

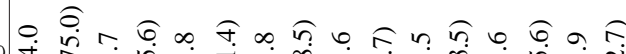

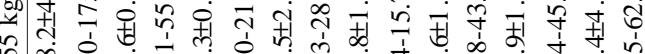

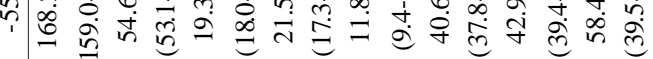

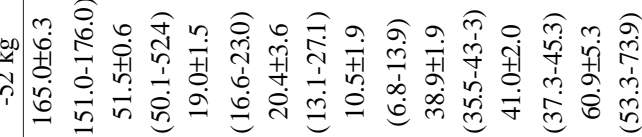

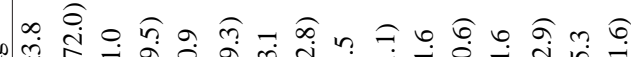

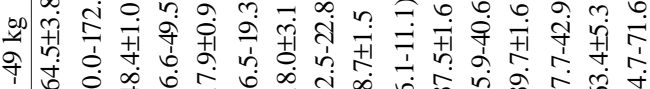

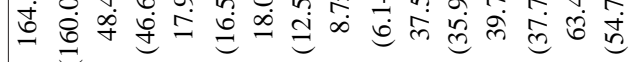

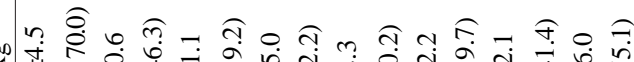

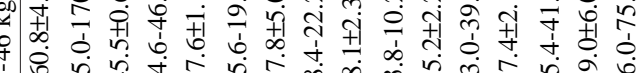

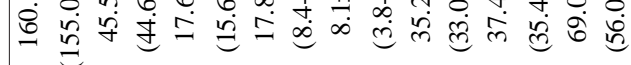

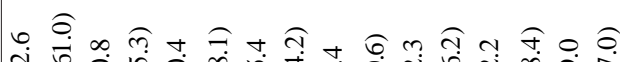

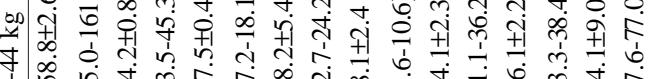

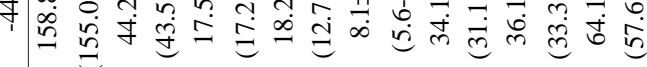

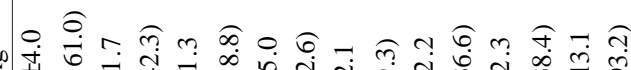

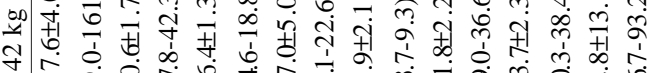

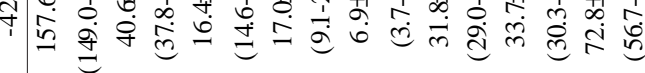

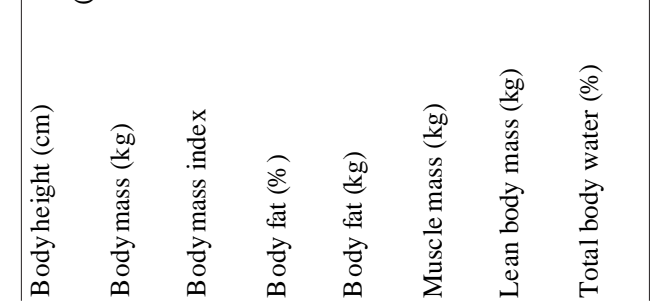




\section{DISCUSSION}

The main goal of this paper was to identify certain anthropometric reference values of male and female junior Croatian taekwondo competitors according to the official weight category. Additionally, the differences between certain categories in these values were investigated. As many authors state that a significant number of taekwondo athletes reduce their weight before the competition (Tsai et al., 2011; Brito et al., 2012; Bes`lija et al.) this reduction probably affects the body fat and hydration loss (Langan-Evans et al., 2011). Also, it seems that out of all anthropometric features, body fat percentage is the only one that distinguishes elite athletes from the non-elite ones (Wazir et al., 2019), putting a light on body fat percentage as being one of the most important characteristics. Related to this, junior taekwondo athletes from this research have shown lower levels of body fat, where percentages for males range from 10.1 to $17.6 \%$ depending on the weight category. These percentages are similar to those reported by other authors (Bridge et al.), although it is not possible to compare thoroughly because other researchers didn't categorize the athletes by weight. Female junior taekwondo athletes have higher body fat percentages than males with a range from 17.0 to $28.8 \%$. Since other authors report values from 19.5 to $24 \%$ it is obvious that the female athletes from this research were similar in these results. A statement that novice taekwondo practitioners have higher levels of body fat than their more experienced peers (Toskovic et al.) has been proven by this research also (Cular et al., 2020). When looking into the differences between the categories, significant differences were found only between the lowest and the highest categories, logically suggesting a relation to weight. By inspection of BMI in both male and female athletes, similar results were noted throughout weight categories which are in accordance with previous studies (Kazemi et al., 2006).

When a body mass reduction is being done, most often before the competition, coaches are mostly concerned about affecting the muscle mass (Langan-Evans et al.). So, their precompetition programs and training are mostly focused on the maintenance of muscle mass and reduction of body fat. However, what is being often forgotten is that fast body mass reduction causes also dehydration (Utter et al.), which could be detrimental to performance and also health in general, especially in younger contestants. Therefore, each coach must know about the minimal hydration limit. This number depends on the athlete's age and body weight, but its mean value is around $60 \%$. This would mean that all athletes that have their total body water percentages below the minimum value of 60 $\%$ are significantly endangering their performance and health. Male junior taekwondo athletes from this study show total body water percentages from 57.4 to $74.8 \%$, with significantly lower percentages in higher weight categories. This significant drop in hydration towards higher weight categories is due to higher body fat and muscle mass values. These values suggest that male athletes, in general, have good hydration status apart from those in heavier categories who are at risk from dehydration and a possible decline in performance. On the other hand, when females are observed, the situation is even more worrying. The range of total body water percentage over categories is from 48.3 to $72.8 \%$, while even five of the heaviest categories fall beneath the minimal hydration value of $60 \%$. When analyzing the effects of minimal hypohydration (2-5\% of body weight) on a significant reduction of sports performance (Naghii, 2000) and its consequences concerning deficits in strength, speed, and endurance (Bonci, 2010) it seems that female athletes from this research have significantly endangered their sports performance and health in general. Researches dealing with the body composition of taekwondo athletes have rarely investigated their total body water percentages until now, and since it is a variable that often causes lacks in performance, and consequently endangers the health of the trainee, it should be monitored and investigated more often.

This is the first paper, to our knowledge, that investigates the reference values of junior taekwondo athletes but based on official weight categories. This is especially important as each weight category warrant different body composition requirements, as seen from significant differences across different variables. For future studies, it would be interesting to explore the levels of motor abilities through different weight categories and also to investigate athletes' metabolic age (not only chronological or biological). Metabolic age tells us how many calories does the body burn at rest, compare to the average basal metabolic rate for people of the same chronological age in the general population.

Moreover, this is one of the rare investigations focusing not only on anthropometric characteristics but also analyzing the hydration of the athletes which proved to be a variable of immense importance in this sport, as being a "weight making" sport. More awareness about the negative effects of dehydration should be raised among coaches as well as athletes themselves. One of the lacks of the current study could be the use of the TANITA diagnostic scale, although its reliability was proved in many types of research (Utter et al.; Quiterio et al., 2009). However, there are conflicting conclusions that prefer standard physiological methods (plasma and urine) of hydration and controlled laboratory sampling multiple times a day. Since a large number of athletes needed to be tested for the determination of reference values, such testing was not an option for this kind of investigation. Authors hope that the introduced benchmarks will help coaches in planning health oriented development and prediction of optimal weight category for their athletes. 


\section{ACKNOWLEDGEMENTS}

This work has been supported by the Croatian Science Foundation, Project No. [IP-2020-02-3366].

CULAR, D.; KEZIC, A. \& TOMLJANOVIC, M. Competidores croatas de taekwondo junior de élite: características morfológicas y valores de referencia de composición corporal. Int. J. Morphol., 39(3):726-731, 2021.

RESUMEN: El objetivo principal de este estudio fue determinar la composición corporal y los valores de referencia antropométricos de los competidores croatas masculinos y femeninos de taekwondo junior según la categoría oficial de peso. Además, se analizó identificar las posibles diferencias en las variables entre las categorías de peso. La muestra estuvo compuesta por 247 participantes junior de los campeonatos nacionales de taekwondo divididos en hombres $(\mathrm{N}=121)$ y mujeres $(\mathrm{N}=126)$. La muestra variable se definió mediante un conjunto de 8 medidas: altura corporal $(\mathrm{cm})$, masa corporal (kg), índice de masa corporal, grasa corporal (\%), grasa corporal $(\mathrm{kg})$, masa muscular $(\mathrm{kg})$, masa corporal magra $(\mathrm{kg})$ y agua corporal total (\%). Los resultados confirmaron estudios previos que demuestran que los practicantes de taekwondo más jóvenes tienen niveles más altos de grasa corporal que sus pares más experimentados (personas mayores). Solo se encontraron diferencias significativas entre las categorías magra y pesada. Los atletas masculinos de taekwondo junior muestran porcentajes de agua corporal total del 57,4 al $74,8 \%$, con porcentajes significativamente más bajos en las categorías de peso más alto, mientras que las atletas femeninas en las categorías más altas, demuestran un nivel preocupante de estado de hidratación, poniendo en peligro su rendimiento y salud en general. Como el primer artículo que investiga los valores de referencia de los atletas de taekwondo junior, pero basado en categorías de peso oficiales, es especialmente importante ya que cada categoría de peso garantiza diferentes requisitos de composición corporal, como se puede observar en las diferencias significativas entre las diversas variables. Los estudios futuros deberían incluir un análisis de las habilidades motoras en todas las categorías de peso y el posible uso del cálculo de la edad metabólica.

PALABRAS CLAVE: Valores normales; Estructura corporal; morfología; Reducción de peso; Hidratación.

\section{REFERENCES}

Beslija, T.; Cular, D.; Kezic, A.; Tomljanovic, M.; Ardigò, L. P.; Dhabhi, W. \& Padulo, J. Height-based model for the categorization of athletes in combat sports. Eur. J. Sport. Sci., 1-10, 2020.

Bonci, L. Sports nutrition for young athletes. Pediatr. Ann., 39(5):300-6, 2010.

Bridge, C. A.; da Silva Santos, J. F.; Chaabène, H.; Pieter, W. \& Franchini, E. Physical and physiological profiles of taekwondo athletes. Sports Med., 44(6):713-33, 2014.

Brito, C. J.; Roas. A. F. C. M.; Brito, I. S. S.; Marins, J. C. B.; Córdova, C. \& Franchini, E. Methods of body mass reduction by combat sport athletes. Int. J. Sport Nutr. Exerc. Metab., 22(2):89-97, 2012.

Burke, L. M.; Cox, G. R.; Wallace, W. A.; Wroble, R. R.; Maffulli, N. \& Kordi, R. Combat Sports Medicine. London, Springer, 2009.
Cular, D.; Beslija, T. \& Kezic, A. Normative values of anthropometric characteristics and body composition in senior croatian taekwondo competitors. Acta Kinesiol., 14(1):5-8, 2020.

Cular, D.; Krstulovic, S. \& Tomljanovic, M. The differences between medalists and non-medalists at the 2008 Olympic games taekwondo tournament. Hum. Mov., 12(2):165-70, 2011.

Cular, D.; Milic, M.; Bilic Pavlinovic, A.; Katic, R.; Kuvacic, G. \& Vrdoljak, J. Somatotype of young taekwondo competitors. Res. Phys. Educ. Sport Health, 2(2):27-33, 2013.

Figueiredo, A. J.; Gonçalves, C. E.; Coelho E Silva, M. J. \& Malina, R. M. Youth soccer players, 11-14 years: maturity, size, function, skill and goal orientation. Ann. Hum. Biol., 36(1):60-73, 2009.

$\mathrm{Gao}, \mathrm{B}$. H. Research on the somatotype features of Chinese elite male taekwondo athletes. Sport Sci., 21:58-61, 2001.

Jeon, M.; Jeon, A. \& Lee, J. H. Differences in body composition of upper and lower limbs in elite taekwondo athletes. Int. J. Morphol., 38(2):265-72, 2020.

Kazemi, M.; Waalen, J.; Morgan, C. \& White, A. R. A profile of olympic taekwondo competitors. J. Sports Sci. Med., 5(CSSI):114-21, 2006.

Langan-Evans, C.; Close, G. \& Morton, J. Making weight in combat sports. Strength Cond. J., 33:25-39, 2011.

Malacko, J.; Doder, D.; Stankovic, V.; Dokmanac, M.; Savic, B. \& Doder, R. A comparative analysis of the morphological characteristics of elite karatekas, judokas, taekwondoists, boxers and wrestlers. Int. J. Morphol., 33(1):24550, 2015.

Malina, R. M.; Peña Reyes, M. E.; Eisenmann, J. C.; Horta, L.; Rodrigues, J. \& Miller, R. Height, mass and skeletal maturity of elite Portuguese soccer players aged 11-16 years. J. Sports Sci., 18(9):685-93, 2000.

Malina, R. M.; Peña Reyes, M. E.; Figueiredo, A. J.; Coelho E Silva, M. J.; Horta, L.; Miller, R.; Chamorro, M.; Serratosa, L. \& Morate, F. Skeletal age in youth soccer players: implication for age verification. Clin. J. Sport Med., 20(6):469-74, 2010.

Naghii, M. R. The significance of water in sport and weight control. Nutr. Health, 14(2):127-32, 2000.

Quiterio, A. L.; Silva, A. M.; Minderico, C. S.; Carnero, E. A.; Fields, D. A. \& Sardinha, L. B. Total body water measurements in adolescent athletes: a comparison of six field methods with deuterium dilution. J. Strength Cond. Res., 23(4):1225-37, 2009.

Sadowski, J.; Gierczuk, D.; Miller, J.; Cieslinski, I. \& Buszta, M. Success factors in male WTF taekwondo juniors. J. Combat Sports Martial Arts, 1:47-51, 2012.

Toskovic, N. N.; Blessing, D. \& Williford, H. N. Physiologic profile of recreational male and female novice and experienced Tae Kwon Do practitioners. J. Sports Med. Phys. Fitness, 44(2):164-72, 2004.

Tsai, M. L; Chou, K. M.; Chang, C. K. \& Fang, S. H. Changes of mucosal immunity and antioxidation activity in elite male Taiwanese taekwondo athletes associated with intensive training and rapid weight loss. Br. J. Sports Med., 45(9):729-34, 2011.

Utter, A. C.; McAnulty, S. R.; Riha, B. F.; Pratt, B. A. \& Grose, J. M. The validity of multifrequency bioelectrical impedance measures to detect changes in the hydration status of wrestlers during acute dehydration and rehydration. J. Strength Cond. Res., 26(1):9-15, 2012.

Wazir, M. R. W. N.; Van Hiel, M.; Mostaert, M.; Deconinck, ñ J. A.; Pion, J. \& Lenoir, M. Identification of elite performance characteristics in a small sample of taekwondo athletes. PLoS One, 14(5):e0217358, 2019.

Corresponding author:

Ana Kezic

Faculty of Kinesiology

University of Split

Nikole Tesle 6

Split - CROATIA

E-mail: anakezic@kifst.hr

Received: 05-02-2021

Accepted: 31-03-2021 